\title{
Suppliers' Performance and
}

\section{Parts Transactions with Customers}

\author{
Yoshinori KONNO \\ Graduate School of Economics, University of Tokyo \\ E-mail: konno@e.u-tokyo.ac.jp
}

\begin{abstract}
This paper investigates the relationship between suppliers' performance and their parts transactions with customers in Japanese automobile industry. We generate a hypothesis focusing on supplier's learning processes, and test it using Japanese auto parts transactions data set during the period 1993-99. Results show that suppliers who prove important to the main customer at the same time maintaining business relationship with numbers of other customers, tend to surpass other suppliers in their performance. In other words, we find how important it is for suppliers to build stable business tie with the main customer and broaden relationship with other various customers.
\end{abstract}

Keywords: Japanese automobile industry, parts transaction, supplier's learning process

\section{Introduction}

This paper aims to generate a hypothesis concerning the relationship between suppliers' performance and their parts transactions with customers in Japanese automobile industry, and test, though restrictively, this hypothesis. Precisely, this paper will clarify that suppliers who prove important to main customer car company at the same time maintaining business relationship with numbers of other customers tend to surpass other suppliers in their performance. We will also discuss its implication.

It has been said that Japanese automakers are inclined to have long-term stable parts transactions relationship with restricted number of parts suppliers, 


\section{Konno}

which have been described as "Keiretsu corporations" with very close relations of capital and personnel. However, Japanese automobile industry of today has been struck by an unprecedented tide of structural reform reflecting slowdown in automobile demand and sharp rise of yen. Suppliers are shifting from a structure depending on a specific automaker for most of transactions and sales but trying to open new business with other automakers. Nonetheless, recent new car development lead-time has become ever shorter, while components technology is innovating rapidly. Suppliers are needed to build strong cooperative relationship with automakers than ever. In fact, not few suppliers station engineers in technical centers of closely related automakers to establish in depth information sharing and coordination of activities from an early stage of technological development.

From an economic point of view, it does seem contradictory that suppliers are "broadening the scope of customers," at the same time, "strengthening business ties with specific automakers." However, when we take particular note on the suppliers' learning process, both efforts are consistent and desirable to be practiced simultaneously. Hereafter, we will generate a hypothesis and conduct limited test of it.

\section{Generating Hypothesis}

\subsection{Regarded Important from Main Customer}

Definitely, information, which is passed on from automakers who are customers to their supplier, play a major role in the suppliers' learning process. In fact, it is commonly observed to have automakers supervise suppliers on product management and quality control. On the other hand, it is often seen among suppliers to receive technical experts from brotherly automakers or send their own men to customer automakers for training. Moreover, it is ever crucial for suppliers to gain information, directly and indirectly, through daily transactions, about technical trend, rivals' doings, and up-to-date needs of automakers and consumers. Alternatively, recently, Japanese top manufacturers are growing in tendency to involve main suppliers in the earliest stage of new technology development projects. Thus, engaging in such co-development projects is essential for suppliers to access and accumulate valuable technological know-how.

Most important in learning from customers is the relationship with the main customer, in this case automaker. Virtually, suppliers' contacts are most frequent with main customers, and main customers' job priorities are higher. It is not uncommon that product development projects aimed at main customers play a major role in building up new core product or production system. Hence, learning from main customers have much larger influence on the supplier's organizations than learning from other customers.

However, even when automaker B is the main customer for supplier A, this does not simply allow supplier A to draw significantly valuable information from automaker B. Among Japanese manufacturers, 
each auto part is usually procured from more than one supplier. Automakers procure same parts from multiple suppliers, and in doing thus they refer to a list in which suppliers are minutely rated by competence and background. As for automakers, especially in co-development projects where highly confidential information needs to be shared, tendency is stronger to partner-up with suppliers whose main customers are themselves. This is because suppliers whose main customer is another automaker might have the potential to lay priority on the other company and, may it not be intentional, leek confidential information to rival companies. In fact, in our interviews, automakers would tie up with their main supplier whose main customers are themselves as well in co-development projects of new technology. Therefore, as long as supplier A is not treated as important supplier from company B, A will hardly gain valuable information from $B$ : Advantages gained through learning from main customer will be reserved.

On the contrary, when tight relationship between makers and suppliers are maintained, in which both companies regard each other as main partner, trust grows and opportunistic breach of information become unlikely: Information of higher confidentiality can be exchanged. Thus, suppliers regarded important from main customers take advantage of learning process compared with suppliers that are not.

\subsection{Customer Scope}

Another thing that is import in suppliers' learning process is to broaden the scope of customers. First, because dealing with many numbers of automakers would allow suppliers access to many different kinds of information, compared to suppliers who limit the number of customers. Additionally, developing and producing virtually same parts for different automakers will engage more numbers of test run and improvement activities during product design and production design procedure, thus quite possibly increase learning effect and experience effect of the supplier.

Second, experiencing numerous customer dealings would increase the ability of knowledge transfer in suppliers. Generally, with some exceptions, it is not easy to develop, produce and deliver auto parts to different automakers without modification, even with same parts. Therefore, in order to transfer knowledge gained through dealings from one customer to another, it is critical to adapt the knowledge into different contexts. Such process involves much questioning and learning-by-doing of "what can be used from knowledge already gained and what ought to be changed," and more transactions offer suppliers more learning opportunity in this matter.

Third, we must consider learning bias. When suppliers are depending too much on transactions with specific automakers, suppliers are apt to overestimate their own competence, naturally because the opportunity to gain objective 
information needed to comprehend their competence is scarce.

Moreover, among various activities going on in a firm, most are repeated and form patterns. Through continuous repetition, activities which proved to be successful are selected and accumulated within the firm as "organizational routine"; such being standard procedures, computer programs, pattern of communication, various know-how, and so on. Generally speaking, in auto parts transactions, suppliers repeat problem-solving in effort to meet the demands of customer automakers, to accumulate successful cases and form routine. Routine allows higher efficiency of operation, however, if the suppliers' learning opportunities are reserved to few customer dealings, it would bias learning process. This is because the supplier might put too much strength on learning the knowledge and experience useful in dealing with the main customer alone and neglect other learning. Likewise, learning bias might occur in "basic corporate behavior principles." Suppliers who restrict business to specific limited numbers of customers in a long term may possibly narrow down and get stuck to one idea of what they regard as business opportunity.

Thus, we believe that suppliers' learning process is improved through business relations with variety of automakers.
2.3. Mutually Complementing Relationship between "Regarded Important from Main Customer" and "Customer Scope"

We further expect that, from discussions in Sections 2.1 and 2.2, suppliers' importance in main customers' eyes and scope of customers are mutually complementing: meeting either one alone would be insufficient. In other words, suppliers are able to merit through learning process only when both priorities are high in main customer's eyes, and business relation with many customers are maintained

We consider that enhanced learning processes improve suppliers' ability. Thus, from above discussion, we can derive a hypothesis: Suppliers who remain highly important to main customer automaker at the same time maintaining business relationship with numbers of other customers, tend to surpass other suppliers in their performance.

\section{Data Analysis}

\subsection{Sample and Data}

This paper will test the hypothesis presented in Section 2, though quite restrictively, on Japanese auto parts transactions during the period 1993-99, utilizing logistic regression analysis method.

We here treat parts transaction as the unit of analysis. That is, we analyze each delivery of parts from supplier to automaker as individual transaction. We referred to IRC Co., Shuyo Jidosha Buhin 200 Hinmoku no Seisan Ryutsu Chosa of 1993 and 1999 to attain data. Nine Japanese car companies are 


\section{Suppliers' Performance}

covered: Toyota, Nissan, Honda, Mitsubishi, Mazda, Suzuki, Daihatsu, Fuji Heavy Industries, and Isuzu. We dropped from sample any kind of auto parts not outsourced, partially or totally. This is because we cannot compare indexes correctly between parts which is totally outsourced and those that are not. Besides, other types of parts were excluded; for example, partial data flaw, not procured by every company, lack of data in either time period, or part category changed. As a result, we obtained 90 types of parts with satisfactory data.

In addition, for data on each supplier company unit, we referred to Nihon no Jidosha Buhin Kogyo: 1992-1993, IRC Co., Nihon no Jidosha Buhin Sangyo no Jittai, 93-nendo Ban, financial report of each company, Nihon Keizai Shinbunsha, Kaisha Soran: Tento, Mijojo Kaisha Ban, 1993, respectively. Numbers of sample is mentioned later.

\subsection{Dependent Variable and Independent Variable}

We will then explain the variables applied in logistic regression analysis. See Table 1 for calculation methods of each variable.

In this paper, we applied Continuity of Parts Transactions (CPT) as suppliers' performance index, which is dependent variable. This is a discrete variable coded as ' 1 ' if parts transaction between supplier and automakers which existed in 1993 has still been continued in 1999, and ' 0 ' if not continued in 1999. Transactions which did not exist in 1993 and had been established in 1999 are excluded from sample.
Indeed, "continuity of parts transactions" is not a straightforward performance index, however, we adopt this as passive performance index believing that "maintained existing parts transactions" suggests "performance was not poor" at least.

On the other hand, first, we adopt as independent variable Regarded Important from Main Customer (RIMC) and Customer Scope (CS). Both variables take values between 0 and 1 , and increase when "regarded important from main customer" or "customer scope" increase. Additionally, we define main customer as the automaker who receive largest number of units of delivery from the supplier for each parts in 1993.

Second, we conduct an analysis applying $\mathrm{RIMC}^{*} \mathrm{CS}$, which is the interaction term of "regarded important from main customer" and "customer scope," as the third independent variable. However, if three variables are applied without modification, multicollinearity problem occur between variables and their interaction term. Therefore, we fix both variables' average value to 0 and adopt this resolved variables and their interaction term.

To sum up discussions in Section 2.1 and 2.2, there are three working hypotheses to test.

Hypothesis 1: RIMC has positive effect on CPT

Hypothesis 2: CS has positive effect on CPT

Hypothesis 3: RIMC ${ }^{*} C S$ has positive effect on $C P T$

\subsection{Customer Segment}

In testing above hypotheses, we divide all parts 


\section{Konno}

Table 1. Calculation Method of Variables

\begin{tabular}{|c|c|c|}
\hline & Variables & Calculation Method \\
\hline $\begin{array}{l}\text { Dependent } \\
\text { variable }\end{array}$ & $\mathrm{CPT}$ & $\begin{array}{l}\text { Discrete variable denoted ' } 1 \text { ' if parts transactions between automaker and } \\
\text { supplier which existed in } 1993 \text { continued in 1999; ' } 0 \text { ' if not continued. }\end{array}$ \\
\hline \multirow{3}{*}{$\begin{array}{l}\text { Independent } \\
\text { variable }\end{array}$} & RIMC & $\begin{array}{l}\text { Suppliers' share in total procurement divided by } 100 \text { in supplier-main } \\
\text { customer parts transactions. }\end{array}$ \\
\hline & $\mathrm{CS}$ & $\begin{array}{l}\text { Sum of square values of each automaker's share in number of parts } \\
\text { delivered from supplier in } 1993 \text { divided by } 100 \text { (as in Herfindahl Index), } \\
\text { then deducted from } 1 .\end{array}$ \\
\hline & $\mathrm{RIMC}^{*} \mathrm{CS}$ & $\begin{array}{l}\text { Deducting mean from each dependent variable RIMC and CS, then multiply } \\
\text { one with the other. }\end{array}$ \\
\hline \multirow{7}{*}{$\begin{array}{l}\text { Parts level } \\
\text { control } \\
\text { variable }\end{array}$} & $\begin{array}{l}\text { Total volume of parts } \\
\text { transactions }\end{array}$ & Log value of suppliers' total parts transactions with 9 automakers in 1993. \\
\hline & Parts market HF & $\begin{array}{l}\text { Sum of square values of suppliers' share in volume of delivery to either of } 9 \\
\text { automakers in parts market divided by } 100 \text { (Herfindahl Index). }\end{array}$ \\
\hline & Market rate & $\begin{array}{l}\text { Transition of total parts procurement of } 9 \text { automakers through 1993-99, } \\
\text { divided by total parts procurement of } 9 \text { automakers in } 1993 .\end{array}$ \\
\hline & Importance to Customer & $\begin{array}{l}\text { Suppliers' share in total procurement made by customer automaker for each } \\
\text { auto parts in } 1993 .\end{array}$ \\
\hline & Automaker dummy & $\begin{array}{l}\text { Dummy value given to } 9 \text { automakers except Isuzu concerning which maker } \\
\text { transaction continued or did not continue in each parts transaction. }\end{array}$ \\
\hline & Parts category dummy & $\begin{array}{l}\text { Dummy value given to } 5 \text { of } 6 \text { categories of auto parts: engine part, engine } \\
\text { electrical component part, car body part, exterior trim part, internal trim } \\
\text { part: car body electrical component part excluded. }\end{array}$ \\
\hline & Main customer dummy & $\begin{array}{l}\text { Dummy value given to } 9 \text { automakers except Isuzu concerning who is the } \\
\text { supplier's main customer company with each parts transaction unit. }\end{array}$ \\
\hline \multirow{6}{*}{$\begin{array}{l}\text { Corporate } \\
\text { level control } \\
\text { variable }\end{array}$} & Degree of dispersion & $\begin{array}{l}\text { Ratio of numbers of categories supplied by each supplier in above } 6 \\
\text { categories in } 1993 .\end{array}$ \\
\hline & Degree of concentration & $\begin{array}{l}\text { Ratio of numbers of types of parts supplied within the category by each } \\
\text { supplier in } 1993 .\end{array}$ \\
\hline & Diversification rate & $\begin{array}{l}\text { Ratio of sales in monetary amounts of non auto parts in total sales of each } \\
\text { supplier company in } 1992 .\end{array}$ \\
\hline & Capital relation dummy & $\begin{array}{l}\text { Dummy value denoted ' } 1 \text { ' if customer automaker held stock of the supplier, } \\
\text { ' } 0 \text { ' if not in each parts transaction unit in } 1992 \text {. }\end{array}$ \\
\hline & Sales amount & Log value of each supplier's sales amount in monetary amounts in 1992. \\
\hline & $\begin{array}{l}\text { Sales amount per } \\
\text { employee }\end{array}$ & $\begin{array}{l}\text { Sales amount per employee in monetary amounts in each supplier company } \\
\text { in } 1992 .\end{array}$ \\
\hline
\end{tabular}

transactions in two groups, that is, transaction with main customer (Main Maker Transaction) and transaction with other customers (Other Maker Transaction). We conducted logistic regression analysis on the latter group alone because "main customer importance" having continuous positive effect on "main maker transaction" is in some sense unquestionable. Thus we took the other samples for testing hypotheses.

Furthermore, 319 supplier companies delivered at least one of 90 parts dealt in this paper to either 9 car companies in 1993. Among them, 13 were $100 \%$ 
Table 2. Descriptive Statistics and Correlation Matrix

(1) Status of Transactions

\begin{tabular}{lccc}
\hline & continue & not continue & total \\
\hline Actual frequency & 982 & 137 & 1119 \\
\hline Relative frequency & 0.88 & 0.12 & 1.00 \\
\hline
\end{tabular}

(2) Descriptive Statistics and Correlation Matrix of Main Variables

sample size $\mathrm{n}=1119$

\begin{tabular}{|c|c|c|c|c|c|c|c|c|c|}
\hline & Variables & M.D & S.D & 1 & 2 & 3 & 3 ' & 4 & 5 \\
\hline 1 & RIMC & 0.63 & 0.29 & 1.00 & & & & & \\
\hline 2 & CS & 0.60 & 0.21 & -0.19 & 1.00 & & & & \\
\hline 3 & $\mathrm{RIMC}^{*} \mathrm{CS}$ & -0.01 & 0.06 & -0.05 & 0.06 & 0.29 & 1.00 & & \\
\hline 4 & Total volume of parts transactions & 5.38 & 0.92 & 0.33 & 0.33 & 0.47 & -0.07 & 1.00 & \\
\hline 5 & Parts market HF & 0.30 & 0.11 & 0.24 & 0.20 & 0.38 & 0.18 & 0.27 & 1.00 \\
\hline 6 & Market rate & -0.12 & 0.44 & 0.12 & -0.09 & 0.02 & -0.08 & 0.10 & 0.06 \\
\hline 7 & Importance to customer & 0.38 & 0.31 & 0.29 & 0.19 & 0.38 & 0.03 & 0.33 & 0.23 \\
\hline 8 & Degree of dispersion & 0.33 & 0.16 & 0.35 & -0.29 & 0.13 & 0.08 & 0.17 & 0.14 \\
\hline 9 & Degree of concentration & 0.20 & 0.19 & 0.35 & -0.18 & 0.17 & -0.03 & 0.11 & 0.12 \\
\hline 10 & Diversification rate & 0.19 & 0.23 & -0.30 & 0.22 & -0.12 & -0.02 & -0.04 & -0.07 \\
\hline 11 & Sales amount & 11.74 & 1.49 & 0.15 & -0.02 & 0.10 & -0.02 & 0.15 & 0.08 \\
\hline 12 & Sales amount per employee & 42.62 & 24.72 & -0.09 & 0.10 & -0.02 & -0.02 & -0.02 & -0.14 \\
\hline & Variables & 6 & 7 & 8 & 9 & 10 & 11 & 12 & \\
\hline 1 & RIMC & & & & & & & & \\
\hline 2 & $\mathrm{CS}$ & & & & & & & & \\
\hline 3 & $\mathrm{RIMC}^{*} \mathrm{CS}$ & & & & & & & & \\
\hline 4 & Total volume of parts transactions & & & & & & & & \\
\hline 5 & Parts market HF & & & & & & & & \\
\hline 6 & Market rate & 1.00 & & & & & & & \\
\hline 7 & Importance to customer & 0.05 & 1.00 & & & & & & \\
\hline 8 & Degree of dispersion & 0.13 & 0.09 & 1.00 & & & & & \\
\hline 9 & Degree of concentration & -0.05 & 0.09 & 0.54 & 1.00 & & & & \\
\hline 10 & Diversification rate & 0.02 & -0.11 & -0.36 & -0.31 & 1.00 & & & \\
\hline 11 & Sales amount & 0.00 & 0.04 & 0.54 & 0.65 & -0.06 & 1.00 & & \\
\hline 12 & Sales amount per employee & -0.01 & -0.02 & -0.09 & -0.07 & 0.05 & 0.21 & 1.00 & \\
\hline
\end{tabular}

Note: Significant at $1 \%$ when absolute value of correlation coefficient is above 0.08 , significant at $5 \%$ when absolute value of correlation coefficient is above 0.06 .

foreign capital supplier and we excluded them from sample because "regarded important from main customer" and "customer scope" in mother country must be more important. Also for 76 suppliers, company unit data could not be attained, thus suppliers data used in this paper is 230. Then 79 have main customer transaction alone, which leaves 151 companies and 1119 parts transactions with customers other than main as our test sample.

As for control variables, we applied many parts level variables and corporate level variables.

\subsection{Results}

Table 3 shows the result of logistic regression analysis. In model 1 RIMC and $\mathrm{CS}$ is the independent variable and in model 2 interaction term 
Konno

Table 3. Logistic Regression Analysis Results ( $\mathrm{n}=1119)$

\begin{tabular}{|c|c|c|c|c|c|c|c|c|c|c|c|c|c|}
\hline \multicolumn{2}{|l|}{ Model } & \multicolumn{3}{|c|}{1 (a) } & \multicolumn{3}{|c|}{$1(\mathrm{~b})$} & \multicolumn{3}{|c|}{2 (a) } & \multicolumn{3}{|c|}{$2(b)$} \\
\hline & & $\beta$ & S.E. & $\mathrm{P}$ & $\beta$ & S.E. & $\mathrm{P}$ & $\beta$ & S.E. & $\mathrm{P}$ & $\beta$ & S.E. & $\mathrm{P}$ \\
\hline \multicolumn{2}{|l|}{ RIMC } & 1.38 & 0.53 & 0.01 & 1.39 & 0.59 & 0.02 & 1.77 & 0.58 & 0.00 & 1.91 & 0.67 & 0.00 \\
\hline \multicolumn{2}{|l|}{$\mathrm{CS}$} & 2.66 & 0.58 & 0.00 & 2.86 & 0.62 & 0.00 & 3.02 & 0.63 & 0.00 & 3.19 & 0.66 & 0.00 \\
\hline \multicolumn{2}{|l|}{ RIMC*CS } & & & & & & & 2.86 & 1.70 & 0.09 & 3.13 & 1.78 & 0.08 \\
\hline \multicolumn{2}{|l|}{ Total volume of parts transactions } & 0.07 & 0.16 & 0.64 & 0.07 & 0.16 & 0.66 & 0.06 & 0.16 & 0.72 & 0.05 & 0.16 & 0.76 \\
\hline \multicolumn{2}{|l|}{ Parts market HF } & 3.21 & 1.15 & 0.01 & 3.34 & 1.18 & 0.00 & 2.84 & 1.17 & 0.02 & 2.99 & 1.19 & 0.01 \\
\hline \multicolumn{2}{|l|}{ Market rate } & 0.51 & 0.40 & 0.20 & 0.51 & 0.40 & 0.20 & 0.56 & 0.41 & 0.16 & 0.56 & 0.40 & 0.16 \\
\hline \multicolumn{2}{|l|}{ Importance to customer } & 4.48 & 0.70 & 0.00 & 4.41 & 0.71 & 0.00 & 4.45 & 0.71 & 0.00 & 4.36 & 0.71 & 0.00 \\
\hline Transaction with Toyota & \multirow{8}{*}{ 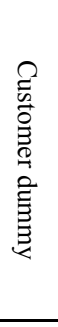 } & 0.92 & 0.64 & 0.15 & 0.84 & 0.65 & 0.19 & 0.94 & 0.65 & 0.15 & 0.86 & 0.66 & 0.20 \\
\hline Transaction with Nissan & & 1.45 & 0.54 & 0.01 & 1.49 & 0.56 & 0.01 & 1.45 & 0.54 & 0.01 & 1.49 & 0.56 & 0.01 \\
\hline Transaction with Honda & & 0.14 & 0.44 & 0.74 & 0.18 & 0.45 & 0.69 & 0.16 & 0.44 & 0.72 & 0.19 & 0.45 & 0.67 \\
\hline Transaction with Mitsubishi & & 0.62 & 0.39 & 0.11 & 0.55 & 0.40 & 0.16 & 0.65 & 0.39 & 0.10 & 0.59 & 0.40 & 0.14 \\
\hline Transaction with Mazda & & 0.52 & 0.39 & 0.18 & 0.51 & 0.40 & 0.20 & 0.52 & 0.39 & 0.18 & 0.50 & 0.40 & 0.21 \\
\hline Transaction with Suzuki & & 0.43 & 0.40 & 0.28 & 0.38 & 0.40 & 0.35 & 0.43 & 0.40 & 0.28 & 0.38 & 0.40 & 0.34 \\
\hline Transaction with Daihatsu & & 0.89 & 0.46 & 0.05 & 0.85 & 0.46 & 0.06 & 0.88 & 0.45 & 0.05 & 0.85 & 0.46 & 0.06 \\
\hline $\begin{array}{l}\text { Transaction with Fuji Heavy } \\
\text { Industries }\end{array}$ & & -0.10 & 0.37 & 0.79 & -0.12 & 0.37 & 0.74 & -0.11 & 0.37 & 0.76 & -0.15 & 0.37 & 0.69 \\
\hline \multicolumn{2}{|l|}{ Engine part } & -0.86 & 0.39 & 0.03 & -1.07 & 0.41 & 0.01 & -0.82 & 0.40 & 0.04 & -1.04 & 0.41 & 0.01 \\
\hline \multicolumn{2}{|l|}{ Engine electrical equipment part } & -0.91 & 0.48 & 0.06 & -0.71 & 0.56 & 0.20 & -0.85 & 0.49 & 0.08 & -0.66 & 0.56 & 0.24 \\
\hline \multicolumn{2}{|l|}{ Car body part } & -0.63 & 0.40 & 0.12 & -0.57 & 0.41 & 0.17 & -0.60 & 0.40 & 0.14 & -0.56 & 0.42 & 0.18 \\
\hline \multicolumn{2}{|l|}{ External trim part } & -0.03 & 0.43 & 0.95 & -0.11 & 0.43 & 0.80 & 0.02 & 0.43 & 0.96 & -0.06 & 0.43 & 0.90 \\
\hline \multicolumn{2}{|l|}{ Internal trim part } & -0.99 & 0.45 & 0.03 & -1.18 & 0.47 & 0.01 & -1.00 & 0.45 & 0.03 & -1.17 & 0.47 & 0.01 \\
\hline Toyota & \multirow{8}{*}{ 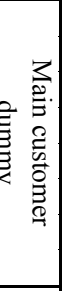 } & 0.33 & 0.76 & 0.67 & 0.71 & 0.80 & 0.38 & 0.53 & 0.76 & 0.49 & 0.94 & 0.80 & 0.24 \\
\hline Nissan & & 0.20 & 0.74 & 0.78 & 0.47 & 0.78 & 0.54 & 0.38 & 0.74 & 0.61 & 0.65 & 0.77 & 0.40 \\
\hline Honda & & -0.52 & 0.77 & 0.50 & -0.39 & 0.81 & 0.63 & -0.31 & 0.77 & 0.69 & -0.17 & 0.81 & 0.84 \\
\hline Mitsubishi & & 0.28 & 0.78 & 0.72 & 0.42 & 0.81 & 0.60 & 0.38 & 0.77 & 0.62 & 0.51 & 0.80 & 0.53 \\
\hline Mazda & & 0.77 & 0.85 & 0.37 & 1.15 & 0.90 & 0.20 & 0.91 & 0.85 & 0.28 & 1.33 & 0.90 & 0.14 \\
\hline Suzuki & & -0.51 & 0.86 & 0.56 & -0.16 & 0.90 & 0.86 & -0.45 & 0.86 & 0.60 & -0.11 & 0.90 & 0.90 \\
\hline Daihatsu & & -1.19 & 0.98 & 0.23 & -0.69 & 1.02 & 0.50 & -1.17 & 0.98 & 0.23 & -0.72 & 1.01 & 0.48 \\
\hline Fuji Heavy Industries & & -7.41 & 20.70 & 0.72 & -6.98 & 20.87 & 0.74 & -7.39 & 20.74 & 0.72 & -6.97 & 20.94 & 0.74 \\
\hline \multicolumn{2}{|l|}{ Degree of dispersion } & & & & -0.26 & 1.05 & 0.80 & & & & -0.65 & 1.07 & 0.55 \\
\hline \multicolumn{2}{|l|}{ Degree of concentration } & & & & -0.63 & 1.07 & 0.55 & & & & -0.75 & 1.07 & 0.49 \\
\hline \multicolumn{2}{|l|}{ Diversification rate } & & & & -1.24 & 0.51 & 0.02 & & & & -1.29 & 0.51 & 0.01 \\
\hline \multicolumn{2}{|l|}{ Sales amount } & & & & -0.07 & 0.11 & 0.54 & & & & -0.05 & 0.11 & 0.67 \\
\hline Sales amount per employee & & & & & 0.00 & 0.01 & 0.56 & & & & 0.00 & 0.01 & 0.67 \\
\hline Capital relation & & & & & 0.46 & 0.62 & 0.46 & & & & 0.41 & 0.62 & 0.51 \\
\hline Constant term & & -2.57 & 0.92 & 0.01 & -1.81 & 1.34 & 0.18 & 0.01 & 1.03 & 0.99 & 0.86 & 1.44 & 0.55 \\
\hline$-2 \log \mathrm{L}$ & & 608.0 & & & 598.7 & & & 605.2 & & & 595.6 & & \\
\hline Negelkerke $R 2$ & & 0.35 & & & 0.36 & & & 0.35 & & & 0.36 & & \\
\hline
\end{tabular}

Note: Yellow cells are $\mathrm{p}<0.10$

is added besides RIMC and CS as independent variable. In each model (a) is parts level variables only and (b) include corporate level variables.

First, in models 1 and 2, RIMC has positive effect on CPT. Besides, model 1 (b) is statistically significant at $5 \%$ while others are statistically significant at $1 \%$. Therefore, hypothesis 1 is supported. Second, in models 1 and 2, CS has positive effect on CPT and all are significant at $1 \%$. Therefore, hypothesis 2 is supported. Third, in model 2, RIMC*CS has positive effect on CPT and all are significant at $10 \%$. Therefore, hypothesis 3 is supported.

This paper will conclude from above analysis 
that suppliers who is important to main customer automaker at the same time maintaining business relationship with numbers of other customers, tend to have advantage over others in parts transactions continuity.

\section{Conclusion}

In plain words, the results suggest how important it is for suppliers to build stable business relation with the main customer and broaden transaction with other various customers. In other words, it is significant for suppliers to broaden customer scope, but if with the sacrifice of existing relation with the main customer, it is not a preferable option.

In fact, suppliers face much advanced technology issues which could only be dealt in collaboration with car manufacturing companies. Therefore, it is crucial for suppliers to prove important in the eyes of main customers and gain more access to confidential information on technology and needs, or join co-development projects on new technology. However, this only will not be sufficient in suppliers' learning process. If suppliers reserve the number of customers, they could get caught in learning bias or become too dependent on specific customer company and lose an attitude to develop and exercise their own strategy. Moreover, in order to manage transaction among different firms, suppliers must be able to adapt the technology or product platform of a specific product to meet different customers' demand. Such competence would only develop, and improve, through learning by doing in numbers of actual dealings with customers. Thus, it is crucial not only to be prove important to main customers, but to broaden customer scope and multiply learning opportunity.

Recently, news media loudly report the “collapse of 'Keiretsu' relationship," nevertheless, discussions in this paper suggest that such point of view is superficial.

Surely, many suppliers are increasing the number of customers, and as a result, competition among suppliers has become intent than ever. However, on the other hand, as clarified in this paper, it is nonetheless important for suppliers to maintain and develop intimate relations with main customers, and as for car manufacturers, it is meaningful to maintain and develop relationships with highly competent core suppliers. Thus, at least between automakers and suppliers who consist Japanese auto parts supplier system, "long term, continuing and collaborative maker-supplier relation" and "competition among suppliers" should be encouraged simultaneously. In other words, "Keiretsu" is not collapsing but its principle characteristic, that is "co-existence of competition and collaboration," would be purified and further developed.

[Received October 10, 2002; accepted January 21, 2003] 
Konno 